\title{
Digitalization as a Main Trend in the Development of Hotel Businesses in the Regions
}

\author{
T. N. Safronova \\ Siberian Federal University \\ Krasnoyarsk, Russia \\ tsafronova@sfu-kras.ru \\ O. M. Evtukhova \\ Siberian Federal University \\ Krasnoyarsk, Russia
}

\author{
O. A. Yabrova \\ Siberian Federal University \\ Krasnoyarsk, Russia \\ T. L. Kamoza \\ Siberian Federal University \\ Krasnoyarsk, Russia
}

\begin{abstract}
The relevance of our research is proved by importance of development of digital technologies in all spheres of social and economic activity and also the need to ensure effective interaction in the sphere of hotel business. The objective of our research was to define the role of information technologies in development of regional hotel business and formation of clusters of the leading hotels of Krasnoyarsk krai on a key factor on according to a key factor. Work is based on own researches of authors, data of state statistics, statistical methods and general scientific methods of the analysis were used. Additionally, in this article we provide some of the data on the state of the hotel market of Krasnoyarsk krai for 2014-18. Despite the proceeding economic and political instability demand for hotel services steadily grows in Krasnoyarsk krai that in turn stimulates development of the hotel market. Competitive advantage of any hotel enterprise is implementation of information technologies. Two clusters of the leading hotel enterprises of Krasnoyarsk krai for a key factor - to use of digital technologies are created. As factors of the objects having an impact on competitive advantage are defined: the average time of the solution of one task on the website of hotel in sec.; search promotion of the website, arrangement in search deliveries on key phrases; level of interaction of audience with publications, in point; multilingualism of the website of the hotel enterprise. Results of the cluster analysis are characterized by the current situation of the hotel market of Krasnoyarsk krai, and are a basis for more profound analysis of activity of the concrete hotel enterprises for the purpose of search of ways of increase in competitive advantages due to use of digital technologies.
\end{abstract}

Keywords: digital technologies, regional market of hotel business, formation of clusters of the leading hotels, Krasnoyarsk krai

\section{INTRODUCTION}

Development of digital economy because digital technologies will become crucial for maintenance of national interests and strengthening of technological sovereignty of Russia in the world market of the knowledge-intensive production $[1,2]$ in the nearest future is extremely important for the Russian Federation. The Government of the Russian Federation developed the measures directed to implementation of the "Digital Economy of the Russian Federation" Program until 2025 and "The development strategy of information society in the Russian Federation for 2017-2030" [3, 4]. A main goal of the Program is creation of an ecosystem of digital economy of the Russian Federation in which data in a digital form will become a key factor of production in all spheres of social and economic activity and also ensuring effective interaction in the sphere of business, science, education, including the system of the relations of the state and its citizens $[3-5,10]$.

In the conditions of fierce competition digital technologies actively come to the hotel market, both to the sphere of automation of internal business processes, and to the sphere of distribution of services of hotels, communications with the guest. Active implementation of digital technologies in hotel business is caused by dynamics of changes of requirements under the influence of bigger availability of information [5$10]$.

\section{Purpose AND Methods}

An objective of this research was definition of a role of information technologies in development of regional hotel business and formation of clusters of the leading hotels of 
Hotels \& Resorts". Services of collective means of placement in 2018771.4 thousand people, including services of hotels and similar means of placement - 555.2 thousand people, 216.2 thousand people used services of specialized means of placement $[11,12]$.

Dynamics of income of collective means of placement from the provided services without the VAT, excises and similar payments (thousand rubles) is presented in figure 1 (fig. 2) [12]. Thus, despite the proceeding economic and political instability demand for hotel services steadily grows in Krasnoyarsk krai that in turn stimulates development of the hotel market. Competitive advantage of any hotel enterprise is implementation of information technologies.

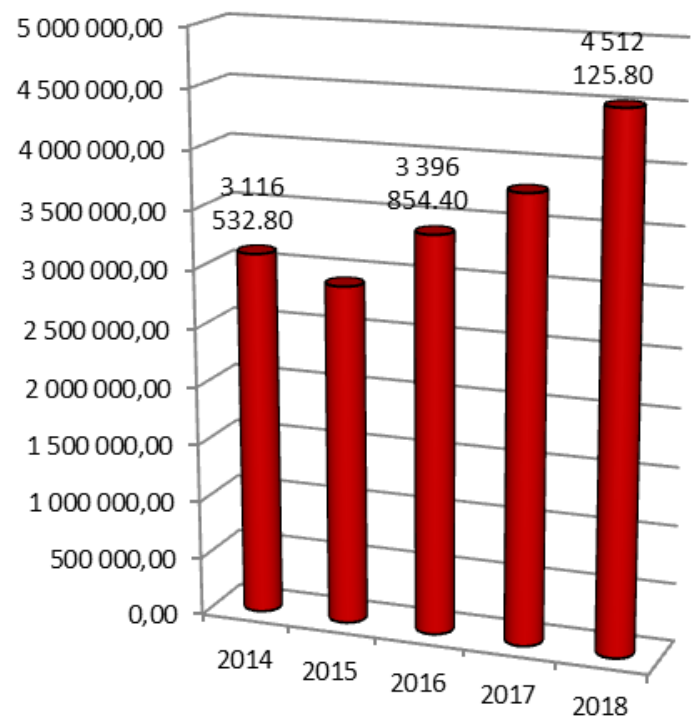

Fig. 2. Dynamics of income of collective means of placement from the provided services without the VAT, excises and similar payments (thousand rubles)

The range of digital technologies in hotel business is rather wide: introduction of ACS and PMS systems on the basis of "cloudy" platforms in traditional business processes that allows not only to book rooms on the website of hotel but also to integrate sales with other online channels, fiscal registrars, unloading of data into UVM Ministry of Internal Affairs, to make online payment, to carry out visa support, to form reports, to work on mobile devices, to make monitoring of social networks and forums for management of reputation of hotel [13-15].

Digital innovations in hotel business which begin to take root actively: digital front desks; the systems of a videoraspoznovaniye and an entrance without key; digital screens and videowalls in zones of expectation and conference rooms; digital hotel rooms; augmented reality (virtual travel on hotel and sights of the area); increase of a role of digital social media, etc. Thus it is possible to summarize that implementation of digital technologies forms competitive advantages of the hotel enterprises. generally concentrated in Krasnoyarsk: "AMAKS Hotels\&Resorts", "Ibis Hotel", "Novotel Hotels", "Hilton 
For formation of clusters of the hotel enterprises of Krasnoyarsk krai for a key factor - to use of digital technologies six leading hotel enterprises having an appreciation of consumers and recommended to Booking.com [16] were defined. All enterprises are in Krasnoyarsk, have 34*. The analysis among the leading hotels is expedient since other enterprises are guided in the activity by leaders of the market. As factors of the objects having an impact on competitive advantage are defined:

- $\mathrm{X} 1$ - the average time of the solution of one task on the website of hotel in sec.;

- $\mathrm{X} 2$ - search promotion of the website, arrangement in search deliveries on key phrases;

- X3 - the level of interaction of audience with publications, in point;

- X4 - multilingualism of the website of the hotel enterprise (tab. 1).

TABLE I. THE FACTORS OF DIGITAL TECHNOLOGIES AFFECTING COMPETITIVE ADVANTAGE OF THE HOTEL ENTERPRISES

\begin{tabular}{|c|c|c|c|c|c|c|}
\hline $\begin{array}{c}\text { Cod } \\
\text { e of } \\
\text { a } \\
\text { fact } \\
\text { or }\end{array}$ & $\begin{array}{c}\text { "City } \\
\text { AMAKC } \\
\text { hotel", 3 } \\
*\end{array}$ & $\begin{array}{c}\text { Snow } \\
\text { Owl } \\
\text { hotel, } \\
\mathbf{3} *\end{array}$ & $\begin{array}{c}\text { Siberia } \\
\text { hotel, } \\
\mathbf{4} *\end{array}$ & $\begin{array}{c}\text { Krasno } \\
\text { yarsk } \\
\text { hotel, 3 } \\
*\end{array}$ & $\begin{array}{c}\text { Hilton } \\
\text { Garden } \\
\text { Inn } \\
\text { Krasnoya } \\
\text { rsk hotel, } \\
\mathbf{4} *\end{array}$ & $\begin{array}{c}\text { Garaz } \\
\mathbf{h} \\
\text { hotel, } \\
\mathbf{3}\end{array}$ \\
\hline $\mathrm{X} 1$ & 20 & 15 & 5 & 9 & 20 & 3 \\
\hline $\mathrm{X} 2$ & 199 & 13 & 270 & 341 & 68 & 49 \\
\hline $\mathrm{X} 3$ & 2,4 & 2,1 & 4,9 & 2,6 & 2 & 1 \\
\hline $\mathrm{X} 4$ & 3 & 2 & 3 & 3 & 24 & 1 \\
\hline
\end{tabular}

Values of indicators of factors after normalization performance are presented in table 2 .

TABLE II. THE NORMALIZED VALUES OF INDICATORS OF FACTORS OF DIGITAL TECHNOLOGIES

\begin{tabular}{|c|c|c|c|c|}
\hline Hotel & X1 & X2 & X3 & X4 \\
\hline 1 & 1.262 & 0.348 & -2.101 & -0.371 \\
\hline 2 & 0.473 & -1.182 & -0.336 & -0.495 \\
\hline 3 & -1.104 & 0.932 & 2.017 & -0.371 \\
\hline 4 & -0.473 & 1.516 & 0.084 & -0.371 \\
\hline 5 & 1.262 & -0.730 & -0.420 & 2.228 \\
\hline 6 & -1.420 & -0.886 & -1.061 & -0.619 \\
\hline
\end{tabular}

The matrix of Euclidean distances between the studied hotel enterprises is given in table 3 .

TABLE III. A MATRIX OF EUCLIDEAN DISTANCES BETWEEN THE STUDIED HOTEL ENTERPRISES

\begin{tabular}{|c|c|c|c|c|c|c|}
\hline Hotel & $\mathbf{1}$ & $\mathbf{2}$ & $\mathbf{3}$ & $\mathbf{4}$ & $\mathbf{5}$ & $\mathbf{6}$ \\
\hline 1 & 0 & 2.469 & 2.438 & 3.025 & 3.504 & 3.139 \\
\hline 2 & 2.469 & 0 & 3.537 & 2.892 & 2.872 & 2.052 \\
\hline 3 & 2.438 & 3.537 & 0 & 2.115 & 4.461 & 3.585 \\
\hline 4 & 3.025 & 2.892 & 2.115 & 0 & 3.881 & 2.835 \\
\hline 5 & 3.504 & 2.872 & 4.461 & 3.881 & 0 & 3.966 \\
\hline 6 & 3.139 & 2.052 & 3.585 & 2.835 & 3.966 & 0 \\
\hline
\end{tabular}

After association by a method of "the closest neighbor" two clusters (tab. 4) are created. The distance between clusters is equal to 3.504 . The sum of distances between objects is equal to 46.771; average distance 3.118 .

TABLE IV. RESULTS OF ASSOCIATION OF EUCLIDEAN DISTANCES

\begin{tabular}{|c|c|c|}
\hline Hotel & $\mathbf{1 , 2 , 3 , 4}$ & $\mathbf{5 , 6}$ \\
\hline $1,2,3,4$ & 0 & 3.504 \\
\hline 5,6 & 3.504 & 0 \\
\hline
\end{tabular}

The analysis of table 4 allows to distinguish two clusters from the considered objects of the hotel market of Krasnoyarsk krai. The first cluster is merging of hotels at numbers 1, 2, 3, 4. On the level of the competition hotels 3 and 4 with cluster distance 2.115 are the closest. Hotels 5 and 6 are allocated in the second cluster with distance 3.881, data of hotel also have similarity concerning factors of competitive advantage due to digital technologies.

\section{RESULTS}

Thus, two clusters of the leading hotel enterprises of Krasnoyarsk krai for a key factor - to use of digital technologies are created. Results of the cluster analysis are characterized by the current situation of the hotel market of Krasnoyarsk krai, and are a basis for more profound analysis of activity of the concrete hotel enterprises for the purpose of search of ways of increase in competitive advantages due to use of digital technologies.

\section{References}

[1] Sagynbekova, "Ampere-second. Digital economy: concepts, prospects, trends of development", International scientific and technical magazine, Theory, Practice, Innovations, no. 4 (28), 2018 [Electronic resource]. Available at: http:www.tpinauka.ru/2018/04/Sagynbekova.pdf (Accesses: 20.11.2019).

[2] R. Bays and R. Hicks, "Definition, concept and measurement of digital economy", Messenger of the international organizations, t. 13, no. 2, pp. 143-172, 2018.

[3] V.P. Kupriyanovsky, S.A. Sinyagov, S.I. Lipatov and etc., "Digital economy - A clever way to work", International Journal of Open Information Technologies, vol. 4, no. 2, pp. 26-33, 2016.

[4] "Digital Economy of the Russian Federation", program, approved by the order of the Government of the Russian Federation of 28 July 2017, no. 1632-r

[5] "About the Development strategy of information society in the Russian Federation for 2017-2030", Decree of the Russian President of 9 May 2017, no. 203.

[6] A.P. Dobrynin, K.Yu. Chernikh and V.P. Kupriyanovsky, "Digital economy - various ways to effective use of technologies", International Journal of Open Information Technologies, vol. 1, no. 4, pp. 4-10, 2016.

[7] I.V. Bogomazova, E.V. Anopriyeva, and T.V. Klimova, "Digital economy in the industry of tourism and hospitality: trends and prospects", Service in Russia and abroad, t. 13, no. 3, p 34, 2019.

[8] H. Varian, "Intelligent Technology", Finance and Development, vol. 53, no. 3, pp. 6-9, 2016.

[9] O.A. Alekseenko and I.V. Ilyin, "Digitalization of the global world and a role of the state in digital economy", The inform. society, no. 2, pp. 25-28, 2018. 
[Electronic resource]. Available at: https://ec.europa.eu/taxation_customs/_ sites/taxation/files/ resources/documents/taxation/gen_info/good_governance_matters/ digital/2014-03-13_fact_figures.pdf (Accessed: 30.11.2019).

[14] A.E. Pastukhova, "Digital technologies as the driver of development of the enterprises of the industry of tourism in Russia (accessible tourism)", Russian regions: prospection, vol. 6, no. 2, p. 150, 2019.

[15] M. De Reuver, C. Sorensen, and R.C. Basole, "The digital platform: a research agenda", Journal of Information Technology, vol. 33, no. 2, pp. 124-135, 2018.

[16] Booking.com [Electronic resource]. Available at: https://www.booking.com/index.ru.h (Accessed: 11.11.2019). 